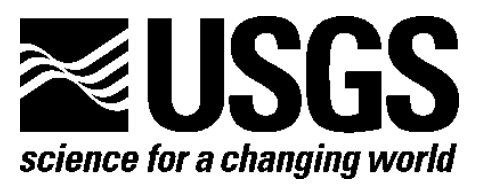

\title{
Geologic Map of the Lower Valley Quadrangle, Caribou County, Idaho
}

By H. Peter Oberlindacher, R. David Hovland, Susan T. Miller, James G. Evans, and Robert J. Miller

Pamphlet to accompany

Scientific Investigations Map 3215 


\section{U.S. Department of the Interior}

RYAN K. ZINKE, Secretary

\section{U.S. Geological Survey}

\section{William H. Werkheiser, Deputy Director, exercising the authority of the Director}

U.S. Geological Survey, Reston, Virginia: 2018

For more information on the USGS-the Federal source for science about the Earth, its natural and living resources, natural hazards, and the environment-visit http://www.usgs.gov/ or call 1-888-ASK-USGS (1-888-275-8747).

For an overview of USGS information products, including maps, imagery, and publications, visit http://store.usgs.gov.

Any use of trade, firm, or product names is for descriptive purposes only and does not imply endorsement by the U.S. Government.

Although this information product, for the most part, is in the public domain, it also may contain copyrighted materials as noted in the text. Permission to reproduce copyrighted items must be secured from the copyright owner.

Suggested citation:

Oberlindacher, H.P., Hovland, R.D., Miller, S.T., Evans, J.G., Miller, R.J., 2018, Geologic map of the Lower Valley quadrangle, Caribou Country, Idaho: U.S. Geological Survey Scientific Investigations Map 3215, 6 p., 1 sheet, scale 1:24,000, https://doi.org/10.3133/sim3215.

ISSN 2329-132X (online) 


\section{Contents}

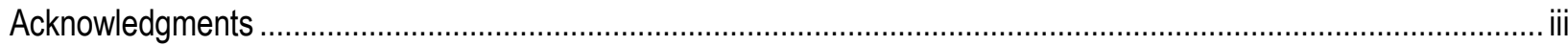

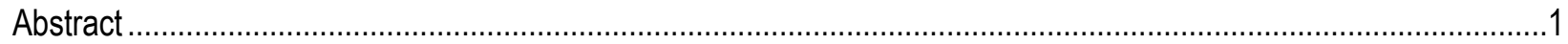

Introduction

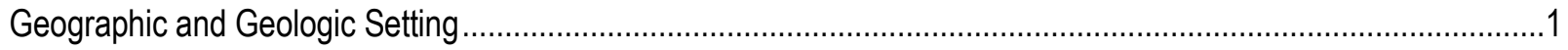

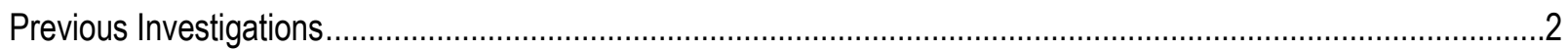

Process and Methodology …………………………………………………………………………....

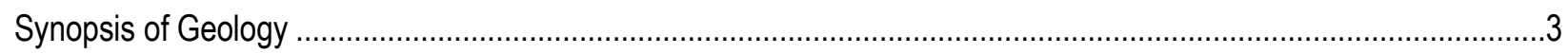

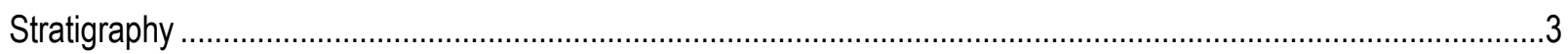

Structure

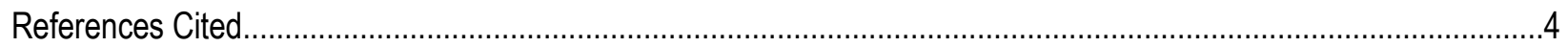

\section{Figures}

Figure 1. Index map showing location of the Lower Valley quadrangle (yellow) ...................................2

\section{Acknowledgments}

The authors would like to acknowledge the many individuals who contributed to the success of this mapping project: to Drs. Calvin H. Stevens and R. Scott Creely of San Jose State University for their technical review and helpful suggestions; to the late W.C. Gere and to Robert A. Gulbrandsen (retired) of the USGS for their guidance in identifying stratigraphic units in the field; to Eve D. Roberts, Richard P. Archdeacon, and Clare E. Shemeta for their valuable field assistance; to the Monsanto and Stauffer Chemical companies who provided access to their phosphate mines and properties; to Phil Moyle of the USGS and Pamela Dunlap of the USGS Spokane field office (retired) and to Claire Landowski of the Menlo Park Publishing Service Center for their considerable efforts in seeing this publication to completion; and to Helen Kayser for final preparation of the digital geologic database. Manuscript and geologic map review by Ed Johnson and a review of digital data by the late Karen Bolm are greatly appreciated. 


\title{
Geologic Map of the Lower Valley Quadrangle, Caribou County, Idaho
}

\author{
By H. Peter Oberlindacher, R. David Hovland, Susan T. Miller, James G. Evans, and Robert J. Miller
}

\begin{abstract}
The Lower Valley 7.5-minute quadrangle, located in the core of the Southeast Idaho Phosphate Resource Area, includes Mississippian to Triassic marine sedimentary rocks, Pliocene to Pleistocene basalt, and Tertiary to Holocene surficial deposits. The Mississippian to Triassic marine sedimentary sequence was deposited on a shallow shelf between an emergent craton to the east and the Antler orogenic belt to the west. The Meade Peak Phosphatic Shale Member of the Permian Phosphoria Formation hosts highgrade deposits of phosphate that were the subject of geologic studies through much of the 20th century. Open-pit mining of the phosphate has been underway within and near the Lower Valley quadrangle for several decades.

\section{Introduction}

\section{Geographic and Geologic Setting}

This report describes the geology of the Lower Valley 7.5-minute quadrangle located in southeastern Idaho (fig. 1). The quadrangle lies about $22 \mathrm{~km}$ northeast of the town of Soda Springs, in the core of the Southeast Idaho Phosphate Resource Area. A paved road provides partial access from State Highway 34 to the west. Major topographic features of the area include the Wooley Range and southern portion of Rasmussen Ridge. The Blackfoot River traverses the southern part of the quadrangle.

The geology of the Lower Valley quadrangle, Idaho, was compiled by James G. Evans in 1998 from 1:12,000-scale mapping by Oberlindacher (1983), Hovland (1981), and Miller (1981, unpublished). This geologic map information was inked onto a 1:24,000-scale greenline mylar of the topographic base map, which was digitally scanned for input into a geographic information system (GIS). The resulting digital geologic map can be queried in many ways to produce a variety of geologic maps. Digital base map data files (topography, roads, towns, rivers, and lakes) are not included; however, they may be obtained from a variety of commercial and government sources. This database is not meant to be used or displayed at any scale larger than 1:24,000.
\end{abstract}




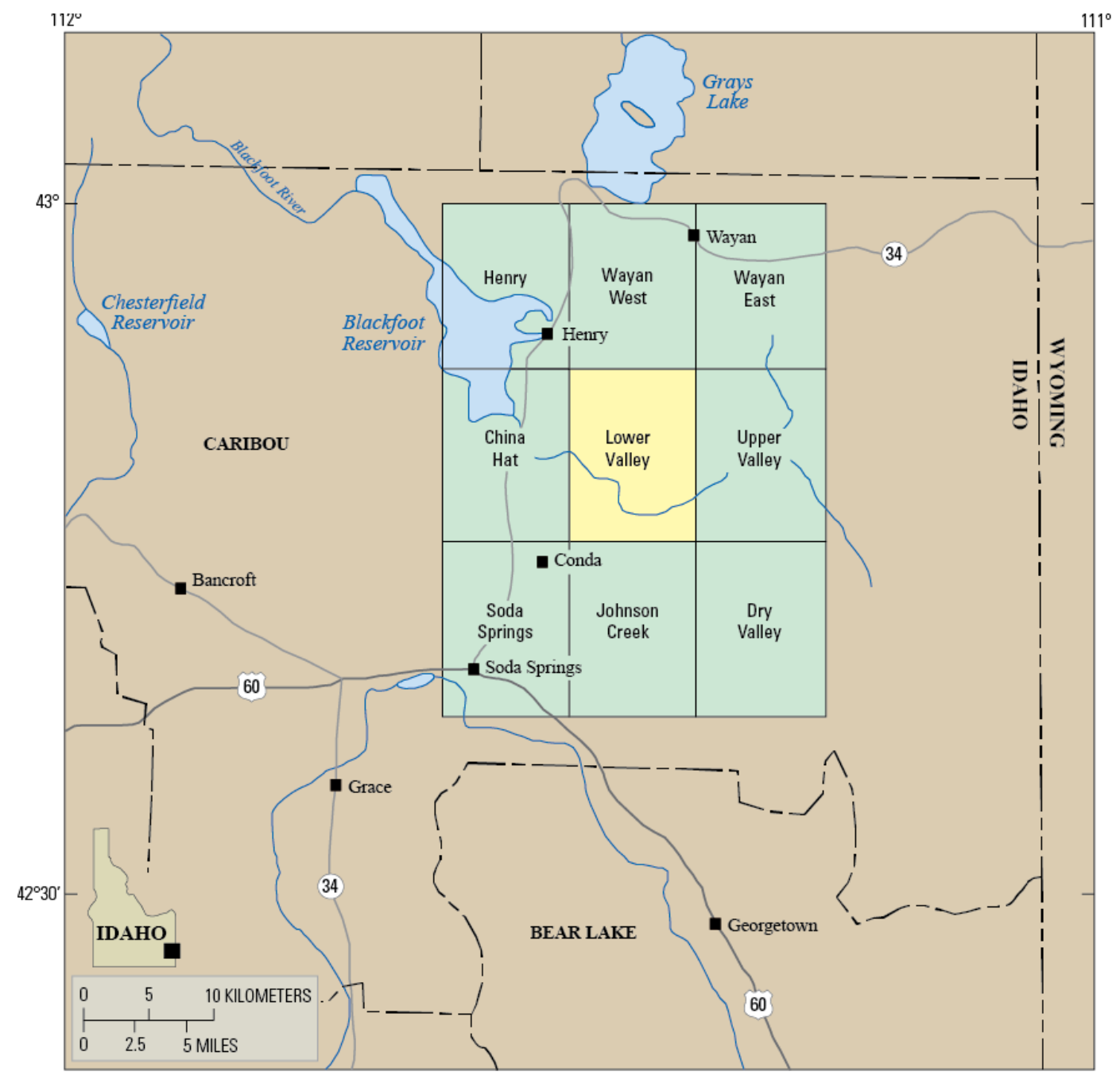

Figure 1. Index map showing location of the Lower Valley quadrangle (yellow).

\section{Previous Investigations}

A considerable body of knowledge on the Phosphoria Formation and related rock units in the Western Phosphate Field has been published. A systematic examination of the Western Phosphate Field was conducted by the U.S. Geological Survey (USGS) from 1909 to 1916 (Mansfield, 1927). In 1947, the USGS resumed its geologic investigation of the Western Phosphate Field and systematically mapped, trenched, sampled and evaluated the phosphate deposits; that work was summarized by McKelvey and others (1959). Although the Lower Valley quadrangle was not included in the mapping project then, a phosphate trench was dug and sampled in NE1/4 sec. 10, T. 7 S., R. 43 E. (Swanson and others, 1953). In 1979, Peter Oberlindacher was encouraged by Dr. McKelvey to map and assess the phosphate resources of the Lower Valley quadrangle.

Geologic mapping near and including the Lower Valley quadrangle can be found in Oberlindacher (1990), Oberlindacher and Roberts-Tobey (1986), Hovland (1981), Rioux and others (1975), Roberts (1982), and Oriel and Platt (1980). The historic literature is too large to list; however, mention of selected 
references is warranted. Pioneering workers such as Mansfield (1918, 1920,1927, 1933), McKelvey and others (1953a, 1953b, 1959, 1967), Sheldon (1959, 1963, 1989), Service and Popoff (1964), Service (1966, 1967), and Gulbrandsen and Krier (1980) concentrated primarily on delineation and evaluation of phosphate resources and on deposit origin. USGS research has also produced significant literature by Gulbrandsen (1966), Piper (1974), Desborough (1977), Altschuler (1980) and others on the unusual chemistry of the Meade Peak Phosphatic Shale Member, the primary source of phosphate ore. Phosphate deposit origin, demand, and commodity studies are reported in Herring (1995), Herring and Fantel (1993), and Herring and Stowasser (1991). The most recent geologic studies, late-1990s to 2003, focused on geoenvironmental issues related to phosphate resource development, mining, and reclamation. A synopsis of the scores of USGS research and related works is presented in Hein (2004).

\section{Process and Methodology}

A preliminary reconnaissance of the Lower Valley quadrangle in 1978 resulted in locating areas for measuring stratigraphic sections, obtaining access to active mine sites and private lands, and field checking type localities of lithologic units.

Geologic field investigation of the area was conducted during a three-month period in 1979 and 1980. The first phase involved measuring detailed stratigraphic sections followed by detailed geologic mapping on a 1:12,000-scale orthophoto base map. The orthophoto map was constructed from 1978, 1:15,840-scale U.S. Department of Agriculture, true-color aerial photographs. Boundaries of mined areas, railroad spurs, and roads were transferred to the base map from aerial photographs using a PG-2 stereo plotter. These boundaries were then field checked during geologic mapping. Stratigraphic sections were measured with Brunton compass and tape. About 150 thin sections were prepared to aid in the interpretation of depositional environments and lithologic description. The classification theme of Dunham (1962) was used for naming the carbonate samples. The U.S. Geological Survey (1978) stratigraphic and time divisions were followed throughout this investigation.

\section{Synopsis of Geology}

\section{Stratigraphy}

The rocks exposed in the Lower Valley quadrangle consist of Mississippian to Triassic marine sedimentary rocks, Pliocene to Pleistocene basalt, and Tertiary to Holocene surficial deposits (table 1, on map sheet). The sedimentary rocks have a maximum cumulative thickness of $835 \mathrm{~m}(2,740 \mathrm{ft})$. The oldest exposed sedimentary bedrock unit is the Late Mississippian Monroe Canyon Limestone, which is overlain by the Pennsylvanian to Permian Wells Formation. Overlying the Wells Formation is the Permian Grandeur Tongue of the Park City Formation, which, in turn, is overlain by the Permian Phosphoria Formation. The Phosphoria Formation includes, in ascending order: the Meade Peak Phosphatic Shale Member, the Rex Chert Member, and the cherty shale member. The Meade Peak Member hosts high-grade deposits of phosphate rock that have been mined by open-pit methods for several decades (Service, 1966, 1967; Hein, 2004). Overlying the Phosphoria Formation is the Early Triassic Dinwoody Formation, which is overlain by the Triassic Thaynes Formation. In the Thaynes Formation the following units, in ascending order, were recognized and mapped: member $A$, member $B$, member $C$, the lower part of the Portneuf Limestone 
Member, the upper part of the Portneuf Limestone Member. The Lanes Tongue of the Ankareh Formation, where present, separates the upper part of the Portneuf Limestone Member from the lower part.

The sedimentary Mississippian to Triassic rock sequence was deposited on a shallow shelf between an emergent craton to the east and the Antler orogenic belt to the west. The depositional environment for the marine sedimentary strata ranges from shallow open-marine to supratidal. Interruption in the major fossil records indicated unconformities for the uppermost Mississippian, the Early and Late Pennsylvanian, and the late Permian.

Isolated exposures of dark-gray, locally vesicular basalt of Pliocene or Pleistocene age occur throughout the quadrangle. The basalt rests unconformably upon Paleozoic, Mesozoic, and Tertiary rocks.

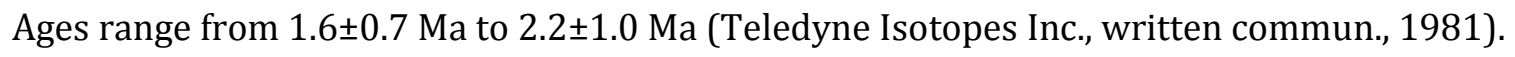

Tertiary and Quaternary surficial deposits consist of older alluvium, hillwash, colluvium, and alluvial fan deposits. Holocene clays, silt, sand, and gravel are restricted to current stream courses and valley bottoms.

\section{Structure}

The Lower Valley quadrangle is situated within the upper plate of the Late Cretaceous Meade Thrust. The principal structural features within the area mapped are subparallel northwest-trending folds, minor imbricate thrust faults, and east-west-trending tear faults. The tear faults have apparent left-lateral offsets of as much as $3 \mathrm{~km}$. High-angle northwest-trending normal faults offset the tear faults and the other structures in the area. Relationships within the quadrangle suggest the following sequence of structural events: folding prior to and synchronous with thrusting; minor imbricate thrusting; tear faulting; highangle normal faulting; and Pliocene or Pleistocene volcanism.

\section{References Cited}

Altschuler, Z.S., 1980, The geochemistry of trace elements in marine phosphorites, Part I, Characteristic abundances and enrichment: Society of Economic Paleontologists and Mineralogists, Special Publication 29, p. 19-30.

Desborough, G.A., 1977, Preliminary report on certain metals of potential economic interest in thin vanadium-rich zones in the Meade Peak Member of the Phosphoria Formation in western Wyoming and eastern Idaho: U.S. Geological Survey Open-File Report 77-341, 27 p.

Dunham, R.J., 1962, Classification of carbonate rocks according to depositional texture, in Ham, W.E., ed., Classification of carbonate rocks, American Association of Petroleum Geologists, Memoir 1, p.108-121.

Gulbrandsen, R.A., 1966, Chemical composition of phosphorites of the Phosphoria Formation: Geochemica et Cosmochimica Acta, v. 30, p. 769-778.

Gulbrandsen, R.A., and Krier, D.J., 1980, Large and rich phosphorous resources in the Phosphoria Formation in the Soda Springs area, southeastern Idaho: U.S. Geological Survey Bulletin 1496, p. 20-21. 
Hein, J.R., ed., 2004, Life cycle of the Phosphoria Formation-From deposition to the post-mining environment: Amsterdam, Elsevier, Handbook of Exploration and Environmental Geochemistry, vol. 8, $635 \mathrm{p}$.

Herring, J.R., 1995, Permian phosphorites; a paradox of phosphogenesis in Scholle, P.A., Peryt, T.M., and Ulmer-Scholle, D.S., eds., The Permian of northern Pangea, v. 2, Sedimentary basins and economic resources: Berlin, Springer-Verlag, p. 292-312.

Herring, J.R., and Fantel, R.J., 1993, Phosphate rock demand into the next century-impact on world food supply: Nonrenewable Resources, v. 2, no. 3, p. 226-246.

Herring, J.R., and Stowasser, W.F., 1991, Phosphate-our nation's most important agricultural mineral commodity and its uncertain future [abs.]: Geological Society of America, Abstracts with Programs, v. 23, no. 5, p. 299-300.

Hovland, R.D., 1981, Geology of the northwest part of the Lower Valley quadrangle, Caribou County, Idaho: San Jose, Calif., San Jose State University, M.S. thesis, 108 p.

Mansfield, G.R., 1918, Origin of the western phosphates of the United States: American Journal of Science, 4th Series, v. 46, no. 274, article 27, p. 591-598.

Mansfield, G.R., 1920, Geography, geology and mineral resources of the Fort Hall Indian Reservation, Idaho: U.S. Geological Survey Bulletin 713, 152 p.

Mansfield, G.R., 1927, Geography, geology, and mineral resources of part of southeastern Idaho with a description of Carboniferous and Triassic fossils, by G. H. Girty: U.S. Geological Survey Professional Paper $152,453 \mathrm{p}$.

Mansfield, G.R., 1933, The western phosphate field, in Ore deposits of the western states [Lindgren Volume]: New York, American Institute of Mining, Metallurgical and Petroleum Engineers, p. 491-496.

McKelvey, V.E., Armstrong, F.C., Gulbrandsen, R.A., and Campbell, R.M., 1953a, Stratigraphic sections of the Phosphoria Formation in Idaho, 1947-48, pt. 2: U.S. Geological Survey Circular 301, 52 p.

McKelvey, V.E., Davidson, D.F., O'Malley, F.W., and Smith, L.E., 1953b, Stratigraphic sections of the Phosphoria Formation in Idaho, 1947-48, pt. 1: U.S. Geological Survey Circular 208, 49 p.

McKelvey, V.E., 1967, The Phosphoria, Park City, and Shedhorn Formations in western phosphate field, in Anatomy of the Western Phosphate Field, a guide to the geologic occurrence, exploration methods, mining engineering, and recovery technology: Intermountain Association of Geologists, 15th Annual Field Conference, p. 15-33.

McKelvey, V.E., Williams, J.S., Sheldon, R.P., Cressman, E.R., Cheney, T.M., and Swanson, R.W., 1959, The Phosphoria, Park City, and Shedhorn Formations in the western phosphate field: U.S. Geological Survey Professional Paper 313-A, 47 p.

Oberlindacher, H.P., 1983, Geology of the southern part of the Wooley Range, Caribou County, Idaho: San Jose, Calif., San Jose State University M.S. thesis, 110 p. 
Oberlindacher, Peter, 1990, Geologic map and phosphate resources of the northeastern part of the Lower Valley quadrangle, Caribou County, Idaho: U.S. Geological Survey Miscellaneous Field Studies Map MF2133, scale 1:12,000.

Oberlindacher, H.P., and Roberts-Tobey, E.D., 1986, Stratigraphy, environment of deposition, and age of a phosphatic unit and adjacent rocks in the Wells Formation, southeastern Idaho, with evidence for a revised Pennsylvanian-Permian stratigraphic boundary: University of Wyoming, Contributions to Geology, v. 24, no. 2, p. 237-241.

Oriel, S.S., and Platt, L.B., 1980, Geologic map of the Preston $1^{\circ} \times 2^{\circ}$ quadrangle, southeastern Idaho and western Wyoming: U.S. Geological Survey Miscellaneous Investigations Series Map I-1127, scale $1: 250,000$.

Piper, D.Z., 1974, Rare earth elements in the sedimentary cycle-a summary: Geochemical Geology, v. 14, no. 4, p. 285-304.

Rioux, R.L., Hite, R.J., Dyni, J.R., and Gere, W.C., 1975, Geologic map of the Upper Valley quadrangle, Caribou County, Idaho: U.S. Geological Survey Geological Map GQ-1194, scale 1:24,000.

Roberts, E.D., 1982, Geology of the southern part of the Wayan West quadrangle, Caribou County, Idaho: San Jose, Calif., San Jose State University, M.S. thesis, 117 p.

Service, A.L., and Popoff, C.C., 1964, An evaluation of the western phosphate industry and its resources (in five parts), pt. 1, Introductory review: U.S. Bureau of Mines Report of Investigations 6485, 86 p.

Service, A.L., 1966, An evaluation of the western phosphate industry and its resources (in five parts), part 3, Idaho: U.S. Bureau of Mines Report of Investigations 6801, 201 p.

Service, A.L., 1967, History and development of the phosphate industry in southeastern Idaho, in Hale, L.A., ed., Anatomy of the Western Phosphate Field: Intermountain Association of Geologists, Fifteenth Annual Field Conference Guidebook, p. 175-176.

Sheldon, R.P., 1959, Geochemistry of uranium in phosphorites and black shales of the Phosphoria Formation: U.S. Geological Survey Bulletin 1084-D, p. D83-D115.

Sheldon, R.P., 1963, Physical stratigraphy and mineral resources of Permian rocks in western Wyoming: U.S. Geological Survey Professional Paper 313-B, p. B49-B273.

Sheldon, R.P., 1989, Phosphorite deposits of the Phosphoria Formation, western United States, in

Notholt, A.J.G., Sheldon, R.P., and Davidson, D.F., eds., Phosphate deposits of the world: Cambridge, U.K., Cambridge University Press, v. 2, p. 55-61.

Swanson, R.W., McKelvey, V.E., and Sheldon, R.P., 1953, Progress report on investigations of western phosphate deposits [Montana-Idaho-Wyoming-Utah]: U.S. Geological Survey Circular 297, 16 p.

U.S. Geological Survey, 1978, Suggestions to authors of the reports of the United States Geological Survey (6th edition): U.S. Geological Survey. 
ISSN 2329-132X (online) https://doi.org/sim3215 